\title{
Seed quality and water use characteristics of maize landraces compared with selected commercial hybrids
}

\author{
Farai Mazvimbakupa ${ }^{1}$, Albert Thembinkosi Modi ${ }^{1}$, and Tafadzwanashe Mabhaudhi ${ }^{1 *}$
}

\begin{abstract}
Understanding seed quality and water use characteristics of maize (Zea mays L.) landraces will improve food security among subsistence farmers who still cultivate them. The objective of this study was to evaluate seed quality and water use characteristics of two maize landraces (GQ1 and GQ2) compared with two commercial hybrids (SC701 and PAN53). Seed quality was determined by the standard germination, electrical conductivity, and tetrazolium tests. A controlled environment study was conducted in which the landraces were compared with hybrids across three water treatments (30\% ETc; 50\% ETc, and 80\% ETc). Although landrace GQ2 performed at par with the hybrids, overall, seed quality tests showed that hybrids had superior seed quality than landraces. This was also confirmed by highly significant emergence results (P $<0.001$ ) from pot trials where SC701 and PAN53 had higher emergence (100\% and $94.44 \%$, respectively) compared with GQ2 (86.11\%) and GQ1 (61.11\%). Subjecting landraces and hybrids to water stress (50\% and 30\% ETc) resulted in shorter plants with fewer leaves and earlier tasselling compared with non-stressed plants ( $80 \%$ ETc). Plant height for the 30\% ETc water treatment was $156.1 \mathrm{~cm}$ compared with $175.8 \mathrm{~cm}$ for the $80 \%$ ETc water treatment, while plants under the $30 \% \mathrm{ETc}$ water treatment tasseled at $105.4 \mathrm{~d}$ compared with $129.5 \mathrm{~d}$ for the $80 \%$ ETc water treatment. The GQ2 landrace continued to perform similar to, and often better, than the hybrid varieties, especially under stress conditions. Yield was poor under controlled conditions. Performance of the GQ2 landrace for both seed quality tests and under controlled conditions shows that landraces remain an important germplasm resource.
\end{abstract}

Key words: Hybrids, landraces, seed quality, water use, Zea mays.

\section{INTRODUCTION}

Maize (Zea mays L.) is the staple food in Southern Africa (Mugo et al., 2002). Resource-poor farmers in South Africa still cultivate maize landraces; these are known for their adaptability to harsh environmental conditions and still produce reasonable yields (Zeven, 1998). This indicates their importance (Mabhaudhi, 2009), particularly in rural communities, and their potential ability to contribute to food security. However, the landraces that resource-poor farmers are familiar with tend to produce relatively low yields despite their adaptability to low-input farming systems (Manzanilla et al., 2011; Mabhaudhi and Modi, 2013). Low yield could be the result of poor quality seed from farmers' prior harvests (Manzanilla et al., 2011). This, coupled with the occurrence of drought, particularly in Sub-Saharan Africa, is a major concern. There is a need for strategies that will encourage sustainable agricultural

\footnotetext{
${ }^{1}$ University of KwaZulu-Natal, School of Agricultural, Earth and Environmental Sciences, Private Bag X01, Scottsville 3209, Pietermaritzburg, South Africa.

*Corresponding author (mabhaudhi@ukzn.ac.za).

Received: 16 July 2014.

Accepted: 22 November 2014.

doi: $10.4067 /$ S0718-58392015000100002
}

production and also identify possible crops for future crop improvement. Thus, attention has now been gravitating towards studying traditional and underutilized crops (Mabhaudhi and Modi, 2013).

Seed testing can be used as a means of providing information about seed quality parameters, such as physiological, physical, phytosanitary, and genetic (FAO, 2010). Physiological parameters of seed quality are related to viability and vigor. Influences on viability have been well documented over the years (Scharpf, 1970). The term viability refers to the ability of a seed to germinate under ideal conditions (Bradbeer, 1988). According to Linington et al. (1996), a germination test is the most useful method to determine the viability of a seed sample. The International Seed Testing Association (ISTA, 1985) defines germination of a seed lot in a laboratory as the emergence and development of the seedling to a stage where the aspect of its essential structures indicate whether or not it is able to develop further into a satisfactory plant under favorable conditions. Soil quality testing under field conditions is often problematic due to the inability to reliably replicate conditions. The use of laboratory testing allows controlling external factors to provide the most uniform, rapid, and complete germination (Kurdikeri et al., 1996). Chemical tests have also been used to 
determine viability. These tests detect chemical reactions that usually, but not always, occur in living systems (Scharpf, 1970). The tetrazolium test is one of these and is the most widely applied biochemical method to examine seed viability.

Although seed quality testing is an important initiative, a better understanding of the effects of drought on landraces is important for improving agricultural systems and their management (Chaves et al., 2003), and thus improve food security. The availability of water during the different stages of crop growth influences the crop's ability to survive (Misra, 1991; 1995). The early stages in plant development (seed germination, seedling emergence, and establishment) are key processes that are sensitive to water availability (Misra et al., 2002; Hadas, 2004). Factors such as water availability in the growing medium and the duration of wetting influence germination. Studies looking at the response of these early stages to water stress have shown water stress as reducing seed germination (Willenborg et al., 2004) and early seedling growth (Mabhaudhi and Modi, 2010). Water stress has also been observed as causing marked decreases in germination rate and seedling vigor (Mabhaudhi and Modi, 2010; Khodarahmpour, 2011).

The aim of the study was to evaluate seed quality and water use characteristics of two landraces compared with two commercial hybrid varieties under controlled environment conditions.

\section{MATERIALS AND METHODS}

\section{Plant material}

Seeds of maize landraces ('GQ1' and 'GQ2') were sourced from local farmers in the Eastern Cape Province, South Africa in 2013. Two commercial hybrids ('SC701' and 'PAN53') were used as control varieties to compare with the landraces. The 'SC701' hybrid is a popular variety among local farmers who grow it for green mealies. This type of mealies is usually harvested during the early dough stage, approximately $3 \mathrm{wk}$ after flowering. It is popular for its late maturity and fairly good tolerance to drought. The 'PAN53' hybrid is a fairly new medium maturity variety.

\section{Seed quality tests}

All experiments were laid out in a randomized complete block design at the University of KwaZulu-Natal's (UKZN) seed technology laboratory in Pietermaritzburg $\left(29^{\circ} 37^{\prime}\right.$ S; $30^{\circ} 23^{\prime} \mathrm{E}$; $669 \mathrm{~m}$ a.s.1.), South Africa. The number of replicates per experiment, as well as the number of seeds used per replicate, varied for each experiment.

For the standard germination test, four replicates of eight seeds from each genotype were germinated in petri dishes. These were lined with double sheets of moistened Whatman filter paper and closed to minimize moisture loss. They were incubated in a germination chamber at alternating temperatures of $20{ }^{\circ} \mathrm{C} / 30{ }^{\circ} \mathrm{C}(16 / 8 \mathrm{~h})$ and a 16:8 h photoperiod for $8 \mathrm{~d}$ (AOSA, 1992). The filter paper was rewetted on a daily basis with deionized water to maintain adequate moisture levels. Daily germination counts were taken based on radicle protrusion of $2 \mathrm{~mm}$ or more. On day 8 , the final germination percentage was calculated according to AOSA (1992) guidelines. This was followed by measuring root and shoot lengths, root:shoot ratio, and seedling fresh mass. In addition, the following indices were calculated:

Germination velocity index (GVI) was calculated based on Maguire's formula (Maguire, 1962):

$\mathrm{GVI}=\mathrm{G}_{1} / \mathrm{N}_{1}+\mathrm{G}_{2} / \mathrm{N}_{2}+\ldots+\mathrm{G}_{\mathrm{n}} / \mathrm{N}_{\mathrm{n}}$

where GVI is the germination velocity index, $G_{1}, G_{2} \ldots G_{n}$ are the number of germinated seeds in first, second... last count, and $\mathrm{N}_{1}, \mathrm{~N}_{2} \ldots \mathrm{N}_{\mathrm{n}}$ are the number of sowing days at the first, second... last count.

Mean germination time (MGT) was calculated according to the formula by Ellis and Roberts (1981):

$$
\mathrm{MGT}=\sum \mathrm{D}_{\mathrm{n}} / \sum \mathrm{n}
$$

where MGT is mean germination time, $\mathrm{n}$ is the number of seeds that germinated on day D, and D is the number of days counted from the start of germination.

Electrical conductivity was measured with the CM100 Model Single Cell Analyzer (Reid \& Associates, South Africa). Only 20 seeds per genotype were used due to limited quantities of maize landrace seeds. Seeds from each genotype were individually weighed and placed into wells filled with $2 \mathrm{~mL}$ distilled water. Electrolyte leakage for each variety was then measured over $24 \mathrm{~h}$.

Seed viability was determined by the tetrazolium (TZ) test. Four replicates of 20 seeds each were used for the TZ test. The seeds were preconditioned for $18 \mathrm{~h}$ by directly soaking them in water. A single-edge razor blade was then used to bisect each seed longitudinally through the midsection of the embryonic axis. Seeds were placed in petri dishes and soaked in a $1 \% \mathrm{TZ}$ solution. Petri dishes were placed in a dark cupboard at room temperature for $6 \mathrm{~h}$. The number of stained seeds was recorded.

\section{Controlled environment experiment}

A pot trial was conducted in a growth tunnel at the Controlled Environment Facility (CEF) at UKZN, South Africa. The environment in the growth tunnels is not fully controlled. However, temperatures $\left(\sim 18 / 33^{\circ} \mathrm{C}\right.$ day/night $)$ and relative humidity ( $60 \%$ to $80 \%$ ) in the tunnels are designed to resemble those of a warm subtropical climate (Modi, 2007). Temperature, relative humidity, and light in the tunnels were monitored with a HOBOnode logger (Onset Computer Corporation, Bourne, Massachusetts, USA).

The experimental layout was a randomized complete block design (RCBD) with two factors: water stress (three levels: $30 \%$ [terminal], 50\% [moderate], and $80 \%$ [control] of crop water requirement [ETc]) and variety (four levels: 'GQ1', 'GQ2', 'SC701', and 'PAN53'), replicated four times. Forty-eight (48) 20 -L pots were filled with 
$15 \mathrm{~kg}$ of soil whose field capacity had previously been gravimetrically determined. Three seeds were planted per pot at a depth of $25 \mathrm{~mm}$. Excess seedlings were thinned soon after emergence to only one plant per pot. Pots were connected to an online drip $\left(2 \mathrm{~L} \mathrm{~h}^{-1}\right)$ irrigation system. Water applied to the $80 \%, 50 \%$, and 30\% ETc treatments totaled 456.96, 285.6, and $171.36 \mathrm{~mm}$ during the study.

The amount of irrigation water was based on ETc calculated using the monthly average reference evapotranspiration $\left(\mathrm{ET}_{0}\right)$ and a crop coefficient $(\mathrm{Kc})$ as described by Allen et al. (1998):

$$
\mathrm{ETc}=\mathrm{ET}_{0} \cdot \mathrm{Kc}
$$

where ETc is the crop's water requirement, $\mathrm{ET}_{0}$ is the reference evapotranspiration, and $\mathrm{Kc}$ is the crop factor.

The $\mathrm{Kc}$ values $\left(\mathrm{Kc}_{\text {initial }}=0.3[2-\mathrm{mo}], \mathrm{Kc}_{\mathrm{med}}=1.15\right.$ [3$\mathrm{mo}]$, and $\mathrm{Kc}_{\mathrm{end}}=1.05$ ([1-mo]) used in this study were obtained from the FAO Irrigation and Drainage Paper nr 56 (Allen et al., 1998).

Fertilizer application was based on a soil analysis report of the soil used in this study. An organic fertilizer (30 $\mathrm{g} \mathrm{N}$ $\mathrm{kg}^{-1}, 15 \mathrm{~g} \mathrm{P} \mathrm{kg}^{-1}$, and $15 \mathrm{~g} \mathrm{~K} \mathrm{~kg}^{-1}$; Gromor, Cato Ridge, KwaZulu-Natal, South Africa) was applied at a rate of $80 \mathrm{~g}$ per pot. Fertilizer was applied in the early stages of plant growth. Weeding of the pots was conducted weekly. Diseases and pests were monitored weekly.

Data collected in the pot trial included seedling emergence, stomatal conductance, chlorophyll content index, soil water content, plant height, and leaf number. Emergence was recorded from the onset of the trial (May 2013) up to $14 \mathrm{~d}$ after planting. The crop was deemed to be established $28 \mathrm{~d}$ after planting when all the seedlings had formed their first true leaves. Thereafter, weekly data were collected for stomatal conductance, chlorophyll content index, soil water content, plant height, and leaf number. Stomatal conductance (SC) was measured with a steady state leaf porometer (Model SC-1, Decagon Devices, Pullman, Washington, USA). Stomatal conductance readings were taken from the abaxial surface of the second youngest fully expanded and fully exposed leaf. The chlorophyll content index (CCI) was measured with a portable chlorophyll content meter (CCM-200; Opti-Sciences, Hudson, New Hampshire, USA) on the adaxial surface of the second youngest fully expanded and fully exposed leaf of each plant. For both SC and CCI, leaves with visible signs of damage or disease were excluded; measurements were taken at midday (12:0014:00 h) and during periods when the soil was drying. Soil water content was monitored with a Theta Probe (ML-2x) connected to an $\mathrm{HH} 2$ handheld moisture meter (Delta-T Devices, Cambridge, UK). Data collection for growth parameters ceased 22 wk after planting when $100 \%$ of the population had reached the tasseling stage. Data collection at harvest (November 2013) included total biomass, ear prolificacy, ear size characteristics, number of kernel rows per ear, number of kernels per row, and harvest index.

\section{Statistical analysis}

All data were subjected to ANOVA with the GenStat statistical system (Version 14, VSN International, Hemel Hempstead, UK). Means of significantly different variables were separated by Duncan's multiple range test in GenStat at a 0.05 probability level.

\section{RESULTS}

\section{Seed quality tests}

The final germination percentage showed highly significant differences $(\mathrm{P}<0.001)$ among maize varieties. High final germination percentages (100\%) were observed for 'GQ2' and 'PAN53' (Figure 1). The GQ1 landrace had the lowest final germination at $67.5 \%$ (Figure 1). Results of germination vigor characteristics indicated highly significant differences $(\mathrm{P}<0.001)$ among varieties for GVI and MGT (Table 3.1). The 'GQ2' landrace germinated at a faster rate and had the lowest MGT (3.57). The 'PAN53' hybrid had high GVI (35.69) followed by 'GQ2'. For GVI, 'GQ1' and 'SC701' were similar although 'SC701' had the highest MGT (4.82) (Table 1, Figure 1).

Results of EC showed highly significant differences $(\mathrm{P}<0.001)$ among varieties. The 'SC701' hybrid recorded

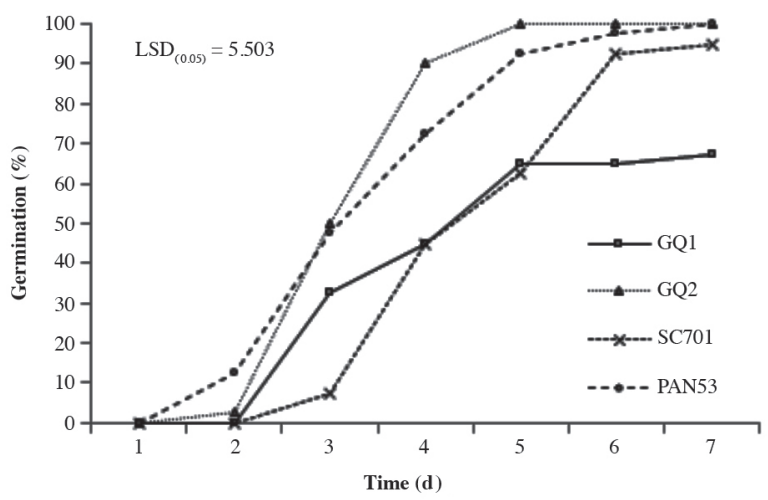

Figure 1. Daily germination percentages of landraces (GQ1 and GQ2) and hybrids (SC701 and PAN53) measured in a standard germination test.

Table 1. Performance of landraces (GQ1 and GQ2) and hybrids (SC701 and PAN53) in a standard germination test.

\begin{tabular}{|c|c|c|c|c|c|c|}
\hline Variety & GVI & MGT & $\begin{array}{l}\text { Root } \\
\text { length }\end{array}$ & $\begin{array}{l}\text { Shoot } \\
\text { length }\end{array}$ & $\begin{array}{l}\text { Root: } \\
\text { shoot }\end{array}$ & $\begin{array}{c}\text { Dry } \\
\text { mass }\end{array}$ \\
\hline & & $\mathrm{d}$ & \multicolumn{2}{|c|}{$\mathrm{mm}$} & & $\mathrm{g}$ \\
\hline GQ1 & $22.20 \mathrm{c}$ & $3.96 \mathrm{~b}$ & $22.50 \mathrm{a}$ & $9.43 \mathrm{~b}$ & $2.61 \mathrm{a}$ & $2.97 \mathrm{~b}$ \\
\hline GQ2 & $36.55 \mathrm{a}$ & $3.57 \mathrm{~b}$ & $34.20 \mathrm{a}$ & $12.60 \mathrm{ab}$ & $2.81 \mathrm{a}$ & $2.77 b$ \\
\hline SC701 & $22.10 \mathrm{c}$ & $4.82 \mathrm{a}$ & $25.50 \mathrm{a}$ & $12.70 \mathrm{ab}$ & $2.11 \mathrm{a}$ & $4.14 \mathrm{a}$ \\
\hline PAN53 & $35.69 \mathrm{~b}$ & $3.78 b$ & $33.40 \mathrm{a}$ & $17.70 \mathrm{a}$ & $1.87 \mathrm{a}$ & $2.85 \mathrm{~b}$ \\
\hline $\operatorname{LSD}_{(\mathrm{P}=0.05)}$ & 0.319 & 0.5232 & 1.351 & 0.5447 & 1.004 & 0.247 \\
\hline$P$ & $<0.001$ & 0.001 & 0.211 & 0.038 & 0.211 & $<0.001$ \\
\hline SED & 0.161 & 0.240 & 0.62 & 0.257 & 0.473 & 0.117 \\
\hline $\mathrm{CV}, \%$ & 26.8 & 4.2 & 33.9 & 31.1 & 31.9 & 5.8 \\
\hline
\end{tabular}

Values with the same letter in a column are similar according to LSD (P = $0.05)$. Means were sorted in descending order.

GVI: Germination velocity index; MGT: mean germination time; LSD: least significant difference; SED: standard error of the difference. 
the highest EC (220.1 $\left.\mu \mathrm{S} \mathrm{g}{ }^{-1}\right)$ followed by 'GQ1' (187.5 $\left.\mu \mathrm{S} \mathrm{g}^{-1}\right)$. On the other hand, 'GQ2' and 'PAN53' had the lowest EC values of 33.5 and $38.5 \mu \mathrm{S} \mathrm{g}^{-1}$, respectively. All seeds tested positive for the tetrazolium test.

A strong positive significant correlation was observed between the following variables: fresh mass and dry mass $(r=0.98 ; P=0.02)$, MGT and dry mass $(r=0.99$; $\mathrm{P}=0.01)$, and root length and GVI $(\mathrm{r}=0.98 ; \mathrm{P}=0.02)$. Although not significant, strong positive correlations were also observed between the following variables: MGT and fresh mass $(r=0.93)$, root length and percentage weight increase during imbibition $(\mathrm{r}=0.90)$; MGT and EC $(\mathrm{r}=$ $0.82)$, percentage mass increase during imbibition and final germination percentage $(r=0.80)$, shoot length and final germination percentage $(r=0.79)$, and shoot length and root length (0.74).

A significant strong negative correlation can be observed between GVI and EC $(r=-0.99 ; \mathrm{P}=0.01)$. Although no significant differences were observed, a strong negative correlation exists between the following variables: root length and EC $(r=-0.95)$, shoot length and $\mathrm{R}$ : $\mathrm{S}$ ratio $(\mathrm{r}=-0.84)$, percentage weight increase during imbibition and EC $(\mathrm{r}=-0.79)$, and MGT and GVI $(\mathrm{r}=-0.76)$.

\section{Controlled environment experiment}

The trend for soil water content showed that SWC was higher at 80\% ETc compared with 50\% ETc and 30\% ETc (Figure 2). This trend was observable throughout the growth period of the crop. Results of seedling emergence showed no differences among varieties because all the treatments were established under optimum conditions. Daily emergence showed highly significant differences $(\mathrm{P}<0.001)$ among varieties. The hybrids (SC701 and PAN53) showed faster and more uniform emergence compared with both 'GQ1' and 'GQ2' (Figure 3). The 'SC701' hybrid had the highest final emergence (100\%) followed by 'PAN53' (94.44\%). Final emergence of the landraces was low with $86.11 \%$ and $61.11 \%$ for 'GQ2'

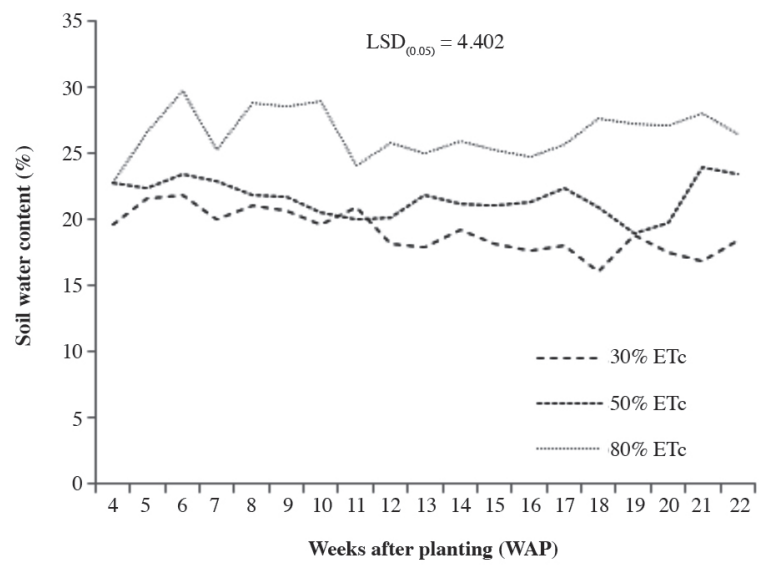

Figure 2. Soil water content for $\mathbf{3 0 \%}$ ETc, $50 \%$ ETc, and $80 \%$ ETc water treatments.

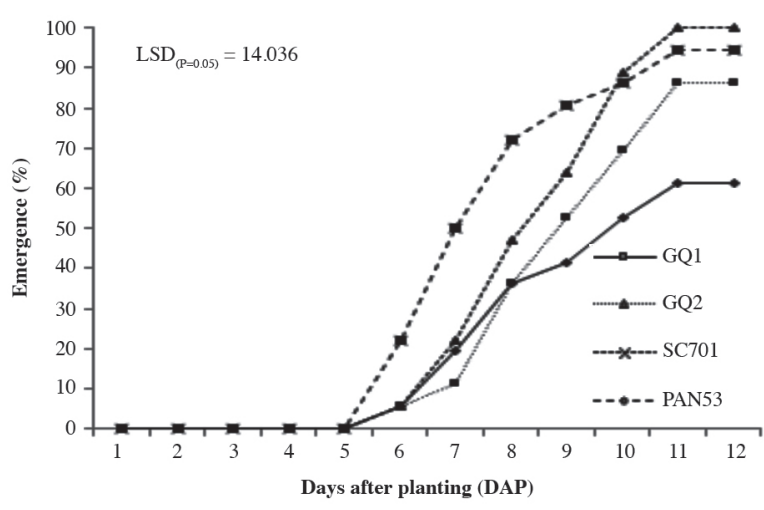

Figure 3. Daily emergence percentage of landraces (GQ1 and GQ2) and hybrids (SC701 and PAN53) over $12 \mathrm{~d}$.

and 'GQ1', respectively. No significant differences were observed for stomatal conductance. Results of SC showed no significant interaction $(\mathrm{P}>0.05)$ between water regimes and varieties. No significant differences $(P>0.05)$ were recorded between water regimes and among varieties (Figure 4). However, stomatal conductance tended to fluctuate throughout crop growth. This was a recurring trend across water regimes. Based on mean values of varieties across water regimes and time, landraces had higher SC than hybrids. The 'GQ2' landrace had the highest SC (58.1 mmol m$\left.{ }^{-2} \mathrm{~s}^{-1}\right)$ followed by 'GQ1' (54.6 $\left.\mathrm{mmol} \mathrm{m} \mathrm{m}^{-2} \mathrm{~s}^{-1}\right)$. The PAN53 and SC701 hybrids had lower values (53.6 and $52.2 \mathrm{mmol} \mathrm{m}^{-2} \mathrm{~s}^{-1}$, respectively). Mean values of water regimes across varieties showed that the $80 \%$ ETc water regime had the highest SC $(55.3 \mathrm{mmol}$ $\left.\mathrm{m}^{-2} \mathrm{~s}^{-1}\right)$. Interestingly, the $30 \%$ ETc water regime had slightly higher SC $\left(54.3 \mathrm{mmol} \mathrm{m}^{-2} \mathrm{~s}^{-1}\right)$ than the $50 \% \mathrm{ETc}$ water regime $\left(54.2 \mathrm{mmol} \mathrm{m}^{-2} \mathrm{~s}^{-1}\right)$.

Results obtained from chlorophyll content index showed a highly significant interaction $(\mathrm{P}<0.001)$ between water regimes and varieties. There were significant differences $(\mathrm{P}<0.05)$ between water regimes. Chlorophyll content index (CCI) was higher at $30 \% \mathrm{ETc}$ and $80 \%$ ETc and these values differed by a small margin (0.05). Highly significant differences were observed among varieties $(\mathrm{P}<0.001)$. The 'PAN53' hybrid had the highest CCI (10.52) followed by both 'GQ2' and 'GQ1' with 10.09 and 10.05, respectively. The 'SC701' hybrid had the lowest CCI with a value of 8.53. Although fluctuations were evident throughout the growth period, the general trend for CCI showed a decrease in CCI for all treatments $(30 \%, 50 \%$, and $80 \%$ ETc) as plant growth progressed toward maturity (Figure 5).

The interaction between water regimes and varieties was not significant $(\mathrm{P}>0.05)$ for plant height. There were also no significant differences $(\mathrm{P}>0.05)$ between water regimes. There were, however, significant differences $(\mathrm{P}$ $<0.05$ ) among varieties (Table 2). At 30\% ETc, 'SC701' had the tallest plants followed by 'GQ2', 'GQ1', and 'PAN53'. At 50\% ETc, 'PAN53' had the tallest plants followed by 'SC701', 'GQ2' and 'GQ1'. Under optimum 

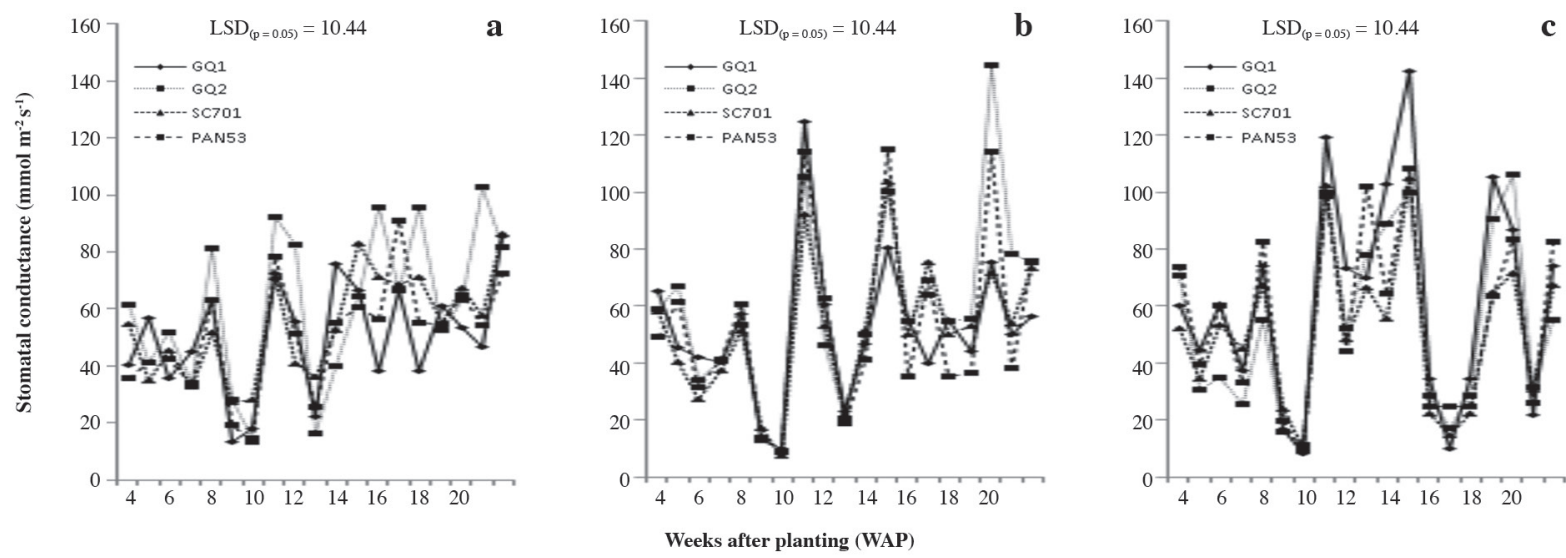

Figure 4. Stomatal conductance of landraces GQ1 and GQ2 compared with hybrids SC701 and PAN53 across water treatments a) $30 \%$ ETc, b) $50 \%$ ETc, and c) $80 \%$ ETc.
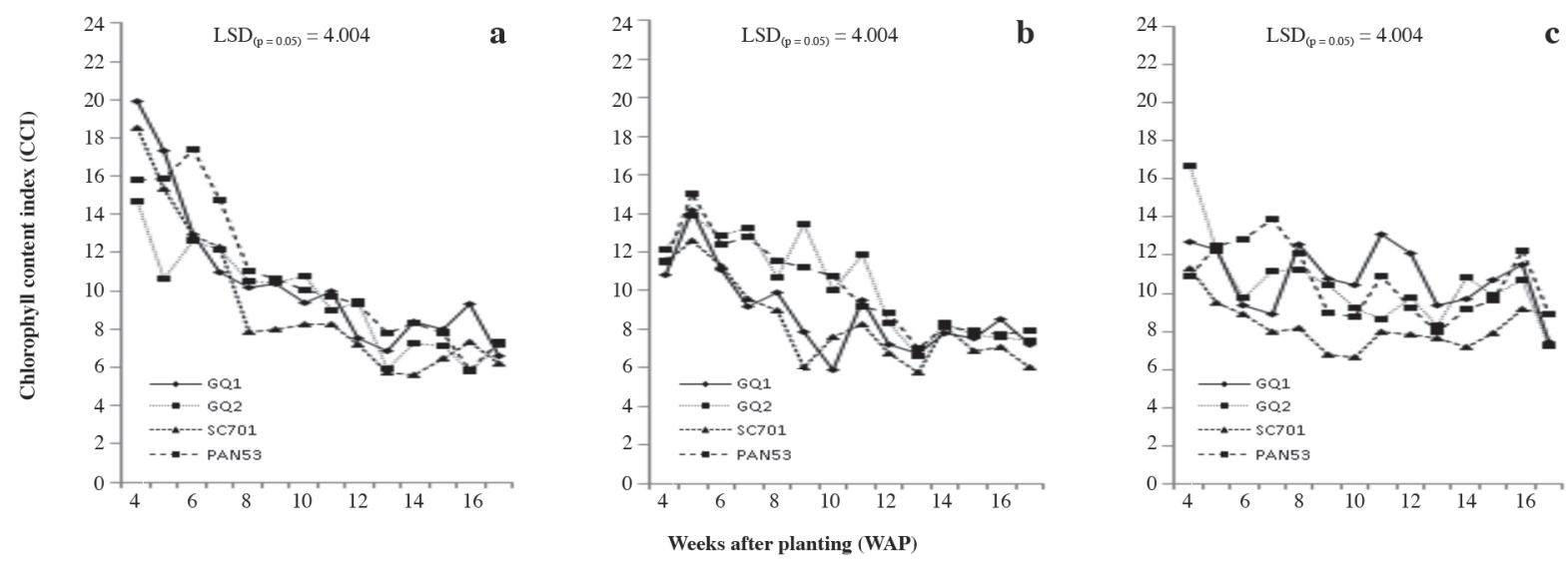

Figure 5. Comparison of chlorophyll content index (CCI) between water treatments: a) $30 \%$ ETc, b) $50 \%$ ETc, and c) $80 \%$ ETc.

Table 2. Plant growth and photosynthetic parameters of landraces (GQ1 and GQ2) compared with hybrids (SC701 and PAN53).

\begin{tabular}{|c|c|c|c|c|}
\hline $\begin{array}{l}\text { Water } \\
\text { treatment }\end{array}$ & Variety & $\begin{array}{l}\text { Height at } \\
\text { tasseling }\end{array}$ & $\begin{array}{l}\text { Leaf number } \\
\text { at tasseling }\end{array}$ & $\begin{array}{l}\text { Time to } \\
\text { tasseling }\end{array}$ \\
\hline & & $\mathrm{cm}$ & & $\mathrm{d}$ \\
\hline \multirow[t]{5}{*}{$30 \%$ ETc } & GQ1 & $144.50 \mathrm{bcd}$ & $10.25 \mathrm{a}$ & $115.90 \mathrm{ab}$ \\
\hline & GQ2 & $146.00 \mathrm{bcd}$ & $9.25 \mathrm{ab}$ & $124.20 \mathrm{ab}$ \\
\hline & SC701 & $193.80 \mathrm{ab}$ & $10.25 \mathrm{a}$ & $94.50 \mathrm{~b}$ \\
\hline & PAN53 & $140.20 \mathrm{~cd}$ & $9.25 \mathrm{ab}$ & $87.50 \mathrm{~b}$ \\
\hline & Mean & 156.10 & 9.81 & 105.40 \\
\hline \multirow[t]{5}{*}{$50 \%$ ETc } & GQ1 & $126.00 \mathrm{~d}$ & $9.71 \mathrm{ab}$ & $105.00 \mathrm{ab}$ \\
\hline & GQ2 & $159.50 \mathrm{abcd}$ & $9.00 \mathrm{ab}$ & $120.00 \mathrm{ab}$ \\
\hline & SC701 & $184.00 \mathrm{abc}$ & $10.00 \mathrm{ab}$ & $214.20 \mathrm{ab}$ \\
\hline & PAN53 & $188.00 \mathrm{abc}$ & $9.25 \mathrm{ab}$ & $115.50 \mathrm{ab}$ \\
\hline & Mean & 164.40 & 9.50 & 116.40 \\
\hline \multirow[t]{5}{*}{$80 \%$ ETc } & GQ1 & $154.20 \mathrm{abcd}$ & 8.75 & $120.80 \mathrm{ab}$ \\
\hline & GQ2 & $174.00 \mathrm{abcd}$ & $9.75 b$ & $117.30 \mathrm{ab}$ \\
\hline & SC701 & $198.20 \mathrm{a}$ & $9.25 \mathrm{ab}$ & $138.20 \mathrm{a}$ \\
\hline & PAN53 & 176.50abcd & $9.50 \mathrm{ab}$ & $141.80 \mathrm{a}$ \\
\hline & Mean & 175.80 & 9.31 & 129.50 \\
\hline $\operatorname{LSD}_{(\mathrm{P}=0.05)}$ & & 10.44 & 1.08 & 34.84 \\
\hline$P$ & & 0.17 & 0.13 & 0.162 \\
\hline SED & & 0.53 & 0.53 & 17.13 \\
\hline $\mathrm{CV}, \%$ & & 4.70 & 3.20 & 12.1 \\
\hline
\end{tabular}

Values with the same letter in a column are similar according to LSD (P = $0.05)$. Means were sorted in descending order.

LSD: Least significant difference; SED: standard error of the difference. conditions (80\% ETc), 'SC701' had the tallest plants while 'GQ1' had the shortest plants. As expected, mean values of varieties across water regimes showed that the $80 \%$ ETc water regime had the tallest plants. This was followed by the $50 \%$ ETc water regime $(164.4 \mathrm{~cm})$ and the $30 \%$ ETc water regime $(156.1 \mathrm{~cm})$. Mean values for water regimes across varieties showed a trend where the SC701 and PAN53 hybrids dominated the GQ1 and GQ2 landraces. The 'SC701' hybrid had the highest plant height $(192 \mathrm{~cm})$ followed by 'PAN53' $(168.2 \mathrm{~cm})$. Plant height for 'GQ2' and 'GQ1' was $159.8 \mathrm{~cm}$ and $141.7 \mathrm{~cm}$, respectively.

With regards to leaf number, there was no significant interaction $(\mathrm{P}>0.05)$ between water regimes and varieties. No significant differences $(\mathrm{P}>0.05)$ were observed between water treatments and varieties (Table 2). Both 'SC701' and 'GQ1' increased leaf number with decreasing water availability, while 'PAN53' and 'GQ2' remained consistent for leaf number. Although there were no significant differences, separation of means revealed differences between 'GQ1'with the lowest number of leaves (8.75), and 'SC701' with the highest number of 
leaves (10.25). Mean values for varieties recorded across water regimes showed that hybrids had more leaves than landraces (mean values were 9.58 and 9.50 for hybrids and landraces, respectively). In terms of water regimes across varieties, the 30\% ETc water treatment had the most leaves (9.81). Although differences were minor, the $80 \%$ ETc water treatment had the least number of leaves (9.31).

There was no significant interaction $(\mathrm{P}>0.05)$ between water regimes and varieties for time to tasselling (Table $2)$. There were, however, significant differences $(\mathrm{P}<$ $0.05)$ between water regimes. At $30 \%$ ETc plants tasseled earlier (105d) than at 50\% ETc (116 d) and 80\% ETc (130 d), respectively (Table 3.2). There were no significant differences $(\mathrm{P}>0.05)$ among varieties. However, mean values of varieties across water regimes showed that 'GQ1' tasseled earlier (114 d) followed by 'PAN53' (115 d), 'SC701' (119 d), and 'GQ2' (121 d).

Results of total biomass showed no significant interaction $(\mathrm{P}>0.05)$ between water regimes and varieties (Table 3). There were significant differences $(\mathrm{P}<0.05)$ between water regimes but not among varieties. A trend could be observed for biomass where $80 \%$ ETc $>50 \%$ $\mathrm{ETc}>30 \% \mathrm{ETc}$. Based on mean values of varieties across water regimes, landraces had higher total biomass than hybrids.

Ear prolificacy showed no significant interaction $(P>0.05)$ between water regimes and varieties (Table $3)$. There were no differences between water regimes or varieties. Separation of means also confirmed that there were no differences. However, mean values of varieties across water regimes showed that landraces had significantly higher ear prolificacy compared with 'SC701' and 'PAN53' (1.25 and 0.92, respectively). This trend was similar to the one observed for total biomass.
For ear size characteristics (ear mass per plant and ear length), there were no significant interactions $(\mathrm{P}>0.05)$ between water regimes and varieties (Table 3 ). The general trend observed using mean values of water regimes across varieties showed that $80 \% \mathrm{ETc}>50 \% \mathrm{ETc}>30 \% \mathrm{ETc}$. The GQ2 and GQ1 landraces performed better than the 'PAN53' and 'SC701' hybrids for ear mass. However, this trend did not explain ear length. The 'SC701' hybrid had the longest plant ears $(78.9 \mathrm{~mm})$ while 'PAN53' had the shortest plant ears $(64.4 \mathrm{~mm})$.

Harvest index (HI) results showed no significant interaction $(\mathrm{P}>0.05)$ between water regimes and varieties. There were also no significant differences $(\mathrm{P}>0.05)$ between water regimes or varieties. The 'PAN53' hybrid attained the highest harvest index at $80 \%$ ETc followed by 'GQ2', 'GQ1', and 'SC701'. The harvest index under water stress conditions was considerably lower for all varieties and 'PAN53' had the lowest HI. Notably, 'SC701' had the highest HI under stress conditions (30\% $\mathrm{ETc})$. The trend in HI was such that $80 \% \mathrm{ETc}>50 \% \mathrm{ETc}$ water $>30 \%$ ETc. Mean values for varieties across water regimes showed that 'GQ1' $(0.24)$ and 'GQ2' $(0.22)$ had higher HI than 'PAN53' (0.23) and 'SC701' $(0.22)$.

\section{DISCUSSION}

Good seed quality is important in any cropping system because it plays an important role in the early growth stages of agricultural crops (Goggi et al., 2008). Good quality seed will enable better field performance in terms of germination, rapid emergence, and vigorous seedling growth (Santos, 2010; Mabhaudhi and Modi, 2010; 2011). Observed differences in varieties for final germination were contrary to most findings in the literature that

Table 3. Yield components of landraces (GQ1 and GQ2) and commercial hybrids (SC701 and PAN53) subjected to three water treatments (30\% FC, 50\% FC, and $80 \%$ FC).

\begin{tabular}{|c|c|c|c|c|c|c|c|}
\hline $\begin{array}{l}\text { Water } \\
\text { treatment }\end{array}$ & Variety & $\begin{array}{c}\text { Total } \\
\text { biomass }\end{array}$ & $\begin{array}{c}\text { Ears } \\
\text { plant }^{-1}\end{array}$ & $\begin{array}{c}\text { Ear mass } \\
\text { plant }^{-1}\end{array}$ & $\begin{array}{c}\text { Ear } \\
\text { length }\end{array}$ & $\begin{array}{c}\text { Kernel rows } \\
\text { ear }^{-1}\end{array}$ & $\begin{array}{c}\text { Kernels } \\
\text { row }^{-1}\end{array}$ \\
\hline & & $\mathrm{g}$ & & $\mathrm{g}$ & $\mathrm{mm}$ & & \\
\hline \multirow[t]{5}{*}{$30 \% \mathrm{ETc}$} & GQ1 & $253.00 \mathrm{~b}$ & $1.00 \mathrm{a}$ & $51.00 \mathrm{ab}$ & $66.80 \mathrm{bc}$ & $1.75 b c$ & $3.08 \mathrm{ab}$ \\
\hline & GQ2 & $241.00 \mathrm{~b}$ & $0.75 \mathrm{a}$ & $52.00 \mathrm{ab}$ & $46.80 \mathrm{~cd}$ & $0.00 \mathrm{a}$ & $0.00 \mathrm{~b}$ \\
\hline & SC701 & $266.00 \mathrm{~b}$ & $1.50 \mathrm{a}$ & $56.00 \mathrm{ab}$ & $61.00 \mathrm{bcd}$ & $4.25 \mathrm{abc}$ & $3.25 \mathrm{ab}$ \\
\hline & PAN53 & $199.00 \mathrm{~b}$ & $0.75 \mathrm{a}$ & $32.00 \mathrm{~b}$ & $26.20 \mathrm{~d}$ & $4.00 \mathrm{abc}$ & $4.25 \mathrm{ab}$ \\
\hline & Mean & 240.00 & 1.00 & 48.00 & 50.20 & 2.50 & 2.65 \\
\hline \multirow[t]{5}{*}{$50 \% \mathrm{ETc}$} & GQ1 & $224.00 \mathrm{~b}$ & $1.50 \mathrm{a}$ & $60.00 \mathrm{ab}$ & $67.00 \mathrm{bc}$ & $5.25 \mathrm{abc}$ & 4.17ab \\
\hline & GQ2 & $265.00 \mathrm{~b}$ & $1.50 \mathrm{a}$ & $50.00 \mathrm{ab}$ & $73.80 \mathrm{bc}$ & $4.25 \mathrm{abc}$ & $2.33 \mathrm{ab}$ \\
\hline & SC701 & $223.00 \mathrm{~b}$ & $1.25 \mathrm{a}$ & $45.00 \mathrm{ab}$ & $79.50 \mathrm{bc}$ & $4.50 \mathrm{abc}$ & $6.46 \mathrm{ab}$ \\
\hline & PAN53 & $295.00 \mathrm{~b}$ & $1.00 \mathrm{a}$ & $70.00 \mathrm{ab}$ & $74.00 \mathrm{bc}$ & $10.75 \mathrm{a}$ & $9.67 \mathrm{a}$ \\
\hline & Mean & 225.00 & 1.31 & 56.00 & 73.60 & 6.19 & 5.66 \\
\hline \multirow[t]{5}{*}{$80 \%$ ETc } & GQ1 & $332.00 \mathrm{ab}$ & $1.25 \mathrm{a}$ & $81.00 \mathrm{ab}$ & $86.00 \mathrm{ab}$ & $3.00 \mathrm{bc}$ & $3.17 \mathrm{ab}$ \\
\hline & GQ2 & $441.00 \mathrm{a}$ & $1.25 \mathrm{a}$ & $206.00 \mathrm{a}$ & $74.50 \mathrm{bc}$ & $2.25 \mathrm{bc}$ & $3.33 \mathrm{ab}$ \\
\hline & SC701 & $289.00 \mathrm{~b}$ & $1.00 \mathrm{a}$ & $68.00 \mathrm{ab}$ & $96.20 \mathrm{a}$ & $4.25 \mathrm{abc}$ & $4.83 \mathrm{ab}$ \\
\hline & PAN53 & $273.00 \mathrm{~b}$ & $1.00 \mathrm{a}$ & 88.00ab & $93.00 \mathrm{a}$ & $8.00 \mathrm{ab}$ & $9.25 \mathrm{a}$ \\
\hline & Mean & 334.00 & 1.12 & 111.00 & 87.40 & 4.38 & 5.15 \\
\hline $\operatorname{LSD}_{(\mathrm{P}=0.05)}$ & & 0.139 & 0.6868 & 138.400 & 29.500 & 6.281 & 6.946 \\
\hline $\mathrm{P}$ & & 0.368 & 0.368 & 0.680 & 0.236 & 0.879 & 0.951 \\
\hline SED & & 0.064 & 0.338 & 68.0 & 14.500 & 3.087 & 3.414 \\
\hline $\mathrm{CV}, \%$ & & 19.3 & 16.1 & 48.7 & 12.3 & 25.2 & 41.6 \\
\hline
\end{tabular}

Values with the same letter in a column are similar according to LSD $(\mathrm{P}=0.05)$. Means were sorted in descending order.

LSD: Least significant difference; SED: standard error of the difference. 
reported landrace seed lots as having inferior quality when compared with hybrid seeds. Similar results were reported by Mabhaudhi and Modi (2010) where landraces performed at par with hybrids in terms of final germination percentage. However, it cannot be concluded that the planting potential of landraces is always equal to that of hybrids given the low performance of 'GQ1'.

Results from the TZ test show inconsistencies with the SG test. According to Naderidarbaghshahi and Bahari (2012), there is a discrepancy between the TZ test and the SG test. It had also been noted by the Department of Agriculture, Food and the Marine (2013) that the TZ test is not suitable for carry-over seed, which is the likely case with landraces. It should also be remembered that the literature points out hybrids to have better seed quality than landraces. Mabhaudhi (2009) attributed hybrid vigor to be limited to hybrid seed. Given the results for MGT where hybrids had a lower MGT, the above statement is in line with research by Mavi et al. (2010), who suggest that MGT is a critical component in determining the emergence performance of a seed lot. Significant differences occurring between varieties could be the result of poor seed quality, particularly for 'GQ1'. It can be suggested that the genetic characteristics of 'GQ1' contribute to poor seed germination and, ultimately, emergence.

Closure of stomata has been identified as an early response to water stress (Khoshvaghti et al., 2013) through reduced transpiration rates. This ultimately leads to reduced net photosynthetic $\mathrm{CO}_{2}$ fixation (Ritchie et al., 1992). Results showed no significant interactions between varieties and water treatments, thereby supporting evidence presented by Chaves (1991) and Cornic and Massacci (1996), who suggest that closure of stomata is more common under field conditions than under controlled environment conditions such as those in the present study.

In the early stages of vegetative growth, plants are more susceptible to water stress than at the middle stages. Thus, water stress during the vegetative stages of crop growth can lead to reduced plant growth (Cominelli et al., 2008). Although differences were not statistically significant, results show plant height to be lower under imposed water stress. With increased water application, plant height increases. Research by Dunford and Vazquez (2005) supports these findings where plants that received more water accumulated more plant material and, therefore, increased in height. Similar results were attained by Khoshvaghti et al. (2013) and Pandey et al. (2000). These results were found for 'SC701' (late maturing hybrid) which had taller plants. This suggests that genotypes with long growth periods are taller on the average than other genotypes (Bert et al., 2003). Although landraces are late maturing (Mabhaudhi, 2009), it must be remembered that hybrid vigor gives hybrids a growth advantage due to their genetic potential. Shorter plant height among landraces supports the reduced loss of water through transpiration, thus potentially improving water use efficiency in those cultivars.

The reproductive phase of maize plant growth is considered to be sensitive to water stress (Çakir, 2004) and causes a marked reduction in yield (Bolaños and Edmeades, 1996). The general trend showing increases in yield and yield components (ear length, ear mass, kernel rows per ear, kernels per row, and harvest index) with increased water application support the idea that plant growth is particularly sensitive to water stress. Reductions in yield and yield components are likely associated with lower evapotranspiration and radiation interception (Stone et al., 2001). Schussler and Westgate (1991) indicated that reduced photosynthetic activity leads to poor seed set in plants grown in pots. This possibly supports the low number of kernels per row and reduced number of kernels per ear. It must be remembered that water stress may be due to the rapid development of water deficit occurring in pots as opposed to crops grown under field conditions (Otegui et al., 1995). The fact that the performance of landraces is at par with hybrids under such tunnel conditions indicates that they could potentially be a viable source to improve food security provided that the yields are similar.

\section{CONCLUSIONS}

From the results obtained, it cannot be concluded that the planting potential of landraces is always equal to that of hybrids because of the low performance of 'GQ1'. Results from the controlled environment experiment also showed that landraces can perform at par with hybrids. Under severe water stress, the prolificacy of landraces may compensate yield. This supports the idea that landraces are drought tolerant. Therefore, landraces should be considered for production in marginal areas because of their potential to contribute to food security. Data obtained from this study will contribute in developing parameters for preliminary parameterization of AquaCrop for maize landraces.

\section{ACKNOWLEDGEMENTS}

We acknowledge the Water Research Commission of South Africa for funding through WRC Project nr K5/2272//4 'Determining water use of indigenous grain and legume food crops'.

\section{LITERATURE CITED}

Allen, R.G., L.S. Pereira, D. Raes, and M. Smith. 1998. Crop evapotranspiration-guidelines for computing crop water requirements. FAO Irrigation and Drainage Paper nr 56. FAO, Rome, Italy.

AOSA. 1992. Seedling evaluation handbook. Contribution $\mathrm{nr} 35$. Association of Official Seed Analysts (AOSA), Washington, DC, USA.

Bert, P.F., I. Jouan, D. Tourvieille, I. de Labrouhe, F. Serre, J. Philippon, et al. 2003. Comparative genetic analysis of quantitative traits in sunflower (Helianthus annuus L.) 2. Characterisation of QTL involved in developmental and agronomic traits. Theoretical Applied Genetics 107:181-189. 
Bolaños, J., and G.O. Edmeades. 1996. The importance of the anthesis-silking interval in breeding for drought tolerance in tropical maize. Field Crops Research 48:65-80.

Bradbeer, J.W. 1988. Seed viability and vigour. p. 95-109. In Seed dormancy and germination. Chapman and Hall, New York, USA.

Çakir, R. 2004. Effect of water stress at different development stages on vegetative and reproductive growth of corn. Field Crops Research 89:1-16.

Chaves, M.M. 1991. Effect of water deficit on carbon assimilation. Journal of Experimental Botany 42:1-16.

Chaves, M.M., J.P. Maroco, and S. Periera. 2003. Understanding plant responses to drought from genes to the whole plant. Functional Plant Biology 30:239-64.

Cominelli, E., M. Galbiati, and C. Tonelli. 2008. Integration of water stress response: Cell expansion and cuticle deposition in Arabidopsis thaliana. Plant Signaling \& Behavior 3:556-557.

Cornic, C., and A. Massacci. 1996. Leaf photosynthesis under drought stress. p. 347-366. In Baker, N.R. (ed.) Photosynthesis and environment. Kluwer Academic Publishers, Dordrecht, The Netherlands.

Department of Agriculture, Food and the Marine. 2013. The tetrazolium test. Department of Agriculture, Food and the Marine, Dublin, Ireland. Available at http://www.agriculture.gov.ie/ animalhealthwelfare/laboratoryservices/seedtestinglaboratory/ tetrazoliumtest/ (accessed 25 October 2013).

Dunford, N.T., and R.S. Vazquez. 2005. Effect of water stress on plant growth and thymol and carvacrol concentrations in Mexican oregano grown under controlled conditions. Journal of Applied Horticulture 7:20-22.

Ellis, R.A., and E.H. Roberts. 1981. The quantification of ageing and survival in orthodox seeds. Seed Science \& Technology 9:373-409

FAO. 2010. Seeds in emergencies: A technical handbook. FAO Plant Production and Protection Paper 202. FAO, Rome, Italy.

Goggi, A.S., P. Caragea, L. Pollak, G. MacAndrews, M. Devries, and K. Montgomery. 2008. Seed quality assurance in maize breeding programs: Tests to explain variations in maize inbreds and populations. Agronomy Journal 100:337-343.

Hadas, A. 2004. Seedbed preparation: The soil physical environment of germinating seeds. In Benech-Arnold, R.L. and R.A. Sanchez (eds.) Handbook of seed physiology: Applications to agriculture. 480 p. Food Product Press, New York, USA.

ISTA. 1985. International rules for seed testing. Rules 1985. Seed Science \& Technology 13:356-513.

Khodarahmpour, Z. 2011. Effect of drought stress induced by polyethylene glycol (PEG) on germination indices in corn (Zea mays L.) hybrids. African Journal of Biotechnology 10:18222-18227.

Khoshvaghti, H., M. Eskandari-Kordlar, and R. Lotfi. 2013. Responses of morphological characteristic and grain yield of maize cultivars to water stress at reproductive stage. Journal of Biodiversity \& Environmental Sciences 3:20-24.

Kurdikeri, M.B., B. Aswathaiah, and S. Rajendra Prasad. 1996. Seed invigoration studies in maize hybrids. Seed Research 21:18-12.

Linington, S., D. Mkhonta, H.W. Pritchard, and J. Terry. 1996. A provisional germination testing scheme for seed of the Compositae. p. 223-235. In Hind, D.J.N., and P.D.S. Caligari (eds.) Compositae: Systematics. Volume 2. Proceedings of the International Compositae Conference, Kew. Royal Botanic Gardens, Kew, UK.

Mabhaudhi, T. 2009. Responses of maize (Zea mays L.) landraces to water stress compared with commercial hybrids. MSc thesis University of KwaZulu-Natal, Pietermaritzburg, South Africa.

Mabhaudhi, T., and A.T. Modi. 2010. Early establishment performance of local and hybrid maize under two water stress regimes. South Africa Journal of Plant and Soil 27:299-304.

Mabhaudhi, T., and A.T. Modi. 2011. Can hydro-priming improve germination vigour, speed and emergence of maize landraces under water stress? Journal of Agricultural Science and Technology B 1:20-28.
Mabhaudhi, T., and A.T. Modi. 2013. Growth, phenological and yield responses of a bambara groundnut (Vigna subterranea L. Verdc) landrace to imposed water stress under field conditions. South African Journal of Plant and Soil 30:69-79.

Maguire, J.D. 1962. Speed of germination - aid in selection and evaluation for seedling emergence and vigour. Crop Science 2:176-177.

Manzanilla, D.O., R.D. Hondrade, V.C.M. Cruz, and D.E. Johnson. 2011. Improving food security through community-based seed systems in the rainfed rice areas of Asia. Journal Policy Brief Series 2011-4. Southeast Asian Regional Center for Graduate Study and Research in Agriculture (SEARCA), Los Baños, Laguna, Philippines.

Mavi, K., I. Demir, and S. Matthews. 2010. Mean germination time estimates the relative emergence of seed lots of three cucurbit crops under stress conditions. Seed Science and Technology $38: 14-25$.

Misra, A.N. 1991. Water use efficiently of pearl millet (Pennisetum americanum L. Leeke) genotypes under mid-season moisture stress. Acta Agronomica Hungarica 40:417-422.

Misra, A.N. 1995. Pearl millet seedling emergence and growth under soil crust. Journal of Environmental Biology 16:113-117.

Misra, A.N., A.K. Biswal, and M. Misra. 2002. Physiological, biochemical and molecular aspects of water stress responses in plants, and the biotechnological applications. Proceedings of the National Academy of Sciences, India-Section B: Biological Sciences 72(2):115-134

Modi, A.T. 2007. Effect of indigenous storage method on performance of taro (Colocasia esculenta (L.) Schott) under field conditions in a warm sub-tropical area. South African Journal of Plant and Soil 24:214-219.

Mugo, S., J. Songa, H. Degroote, and D. Hoisington. 2002. Insect resistant maize for Africa (IRMA) Project (overview). Syngenta Symposium "Perspectives on the Evolving Role of Private/Public Collaborations in Agricultural Research", Washington, DC. 25 June 2002. Sustainable Agriculture, Washington, D.C., USA.

Naderidarbaghshahi, M., and B. Bahari. 2012. Assessment the relationship between seed vigor tests and seed field performance of some forage crops of Iran. International Journal of Agriculture and Crop Sciences 4:1763-1766.

Otegui, M.E., M.G. Nicolini, R.A. Ruiz, and P.A. Dodds. 1995 Sowing date effects on grain yield components for different maize genotypes. Field Crops Research 40:87-94.

Pandey, R.K., J.W. Maranville, and M.M. Chetima. 2000. Deficit irrigation and nitrogen effects on maize in a Sahelian environment. II. Shoot growth. Agricultural Water Management 46:15-27.

Ritchie, S.W., J.J. Hanway, and G.O. Benson. 1992. How a corn plant develops. Special Report 48.25 p. Iowa State University, Cooperative Extension Service, Ames, Iowa, USA. Available at http://maize. agron.iastate.edu/corngrows.html (accessed May 2014).

Santos, B.M. 2010. Seed quality and seeding technology Horticultural Sciences Department, University of Florida Extension Bulletin Cooperative Extension Services, Institute of Food and Agricultural Sciences (IFAS), Florida, USA.

Scharpf, R.F. 1970. Seed viability, germination and radicle growth of dwarf mistletoe in California. USDA Forest Service Research Paper PSW-59. 18 p. Pacific Southwest Forest and Range Experimental Station, Berkeley, California, USA.

Schussler, J.R., and M.E. Westgate. 1991. Maize kernel set at low water potential. 1 . Sensitivity to reduced assimilates during early kernel growth. Crop Science 31:1189-1195.

Stone, P.J., D.R. Wilson, J.B. Reid, and R.N. Gillespie. 2001. Water deficit effects on sweet corn. I. Water use, radiation use efficiency, growth, and yield. Australian Journal of Agricultural Research 52:103-113

Willenborg, C.J., R.H. Gulden, E.N. Johnson, and S.J. Shirtliffe. 2004. Germination characteristics of polymer-coated canola (Brassica napus L.) seeds subjected to moisture stress at different temperatures. Agronomy Journal 96:786-791.

Zeven, A.C. 1998. Landraces: A review of definitions and classifications. Euphytica 104:127-139. 